\title{
NONSENSE MUTATION IN FACTOR VIII GENE OF A SEVERE HAEMOPHILIAC PATIENT WITH ANTI-FACTOR VIII ANTIBODY
}

\author{
Sadaaki MikamI, ${ }^{1}$ Takuya Nishimura, ${ }^{1}$ Hiroyuki NaKa, ${ }^{1}$ \\ Kuninori Kuze, ${ }^{1}$ Hiromu FuKuI, ${ }^{1}$ Masahide Tone, ${ }^{2}$ \\ and Tamotsu Hashimoto-Gotoh ${ }^{2}$ \\ ${ }^{1}$ Department of Pediatrics, Nara Medical College, Kashihara, \\ Nara 634, Japan \\ "Laboratory for Molecular Biology, Pharma Research Laboratories, \\ Hoechst Japan Limited, Minamidai I, Kawagoe, \\ Saitama 350, Japan
}

\begin{abstract}
Summary A nonsense mutation was found in exon 23 of the factor VIII gene of a haemophiliac patient with anti-factor VIII antibody. Genomic DNA of lymphocyte cells from the patient analyzed by Southern blot analysis with various segments of factor VIII cDNA revealed that the TaqI site in exon 23 was erased in the patient gene. The $0.3 \mathrm{kbp}$ nucleotide sequence of the exon 23 was cloned and sequenced, and the substitution of nonsense (TGA) codon for the arginine (CGA) codon was found to be the possible cause of the factor VIII deficiency.
\end{abstract}

Key Words factor VIII gene, nonsense mutation, haemophiliac, inhibitor

\section{INTRODUCTION}

Haemophilia $\mathrm{A}$ is an X-linked recessive bleeding disorder caused by the molecular alteration of factor VIII, and is observed at a frequency of $10^{-4}$ in males. Recently, cDNA for factor VIII has been cloned and sequenced entirely (Wood et al., 1984; Toole et al., 1984). The gene encodes a protein with 2,351 amino acid residues including the initiation codon (position -19). Molecular deficiencies have been reported in factor VIII by several independing groups (Antonarakis et al., 1985; Gitschier et al., 1985, 1986; Youssoufian et al., 1986, 1987a). Since the size of factor VIII gene is $186 \mathrm{kbp}$ long containing 26 exons, complete sequence of the gene is not easily determined for each of the patient, and the genetic polymorphism at the various sites are analyzed as a linked marker of the genetic defect.

Received July 12, 1988; revised version received August 2, 1988; Accepted August 17, 1988 
In this report, we found a nonsense (CGA to TGA) mutation, which resulted in the termination at amino acid residue position 2209 in exon 23 of the factor VIII gene. This severe haemophiliac patient had anti-factor VIII antibodies. This patient is one of 64 Japanese haemophilia A patients and 6 cases with anti-factor VIII antibodies studied by us.

\section{CASE REPORT}

The patient (15 years of age, male) had a severe haemophilia A, having less than $1 \%$ of factor VIII coagulant activity (VIIIC) assayed by one stage method (Hardisty and Macpherson, 1962) and less than $0.1 \%$ of factor VIII coagulant antigen (VIIICag) assayed by IRMA (Peake et al., 1979). He had knee joint haemorrhages and repeated haematuria. At 3 years of age, anti-factor VIII antibody (inhibitor) with maximum titers of 130 Bethesda units $/ \mathrm{ml}$ was detected. His mother is a carrier (VIIIC 45\%, VIIICag 49\%, von Willebrand factor antigen $100 \%$ ). $\mathrm{He}$ has three sisters. One of them is healthy and the other two are heterozygous carriers as detected by coagulant assays and $B c l \mathrm{I}$ polymorphism (Nishino et al., 1987).

\section{METHODS}

DNA preparation and RFLP analysis. Genomic DNAs of the 70 Japanese haemophiliac patients were isolated from leukocytes and digested with TaqI restriction endonuclease in combination with various other restriction enzymes for RFLPs (restriction fragment length polymorphisms) analysis. Gel electrophoresis, Southern blot hybridization and radioisotope lebeling were performed as described previously (Maniatis et al., 1982). DNA probes for Southern blot analysis were those as described elesewhere (Antonarakis et al., 1985; Mikami et al., 1988). Two 17-mer oligonucleotides used as primers for DNA sequencing and a 90-mer probe used for library screening were synthesized with the DNA synthesizer (ABI 380 Model; Applied Biosystems Inc., Foster City, Calif., USA).

\section{RESULTS}

Genomic DNAs were isolated from leukocytes of patients and digested with restriction endonuclease TaqI for restriction fragment length polymorphism (RFLPs) analysis. Southern blot analysis was performed using two different types of probes, one (probe A) covering exons from 1 to 12 and the other (robe $\mathrm{B}+\mathrm{C}$ ) covering exons from 14 to 26 (Fig. 1). In the initial survey of the DNAs, it was revealed that DNA from one such patient showed no difference in the Southern blot pattern compared with the normal human DNA when probe A was used (Fig. 2, left two columns) but showed an additional $3.8 \mathrm{kbp}$ fragment instead of two $1.4 \mathrm{kbp}$ and 

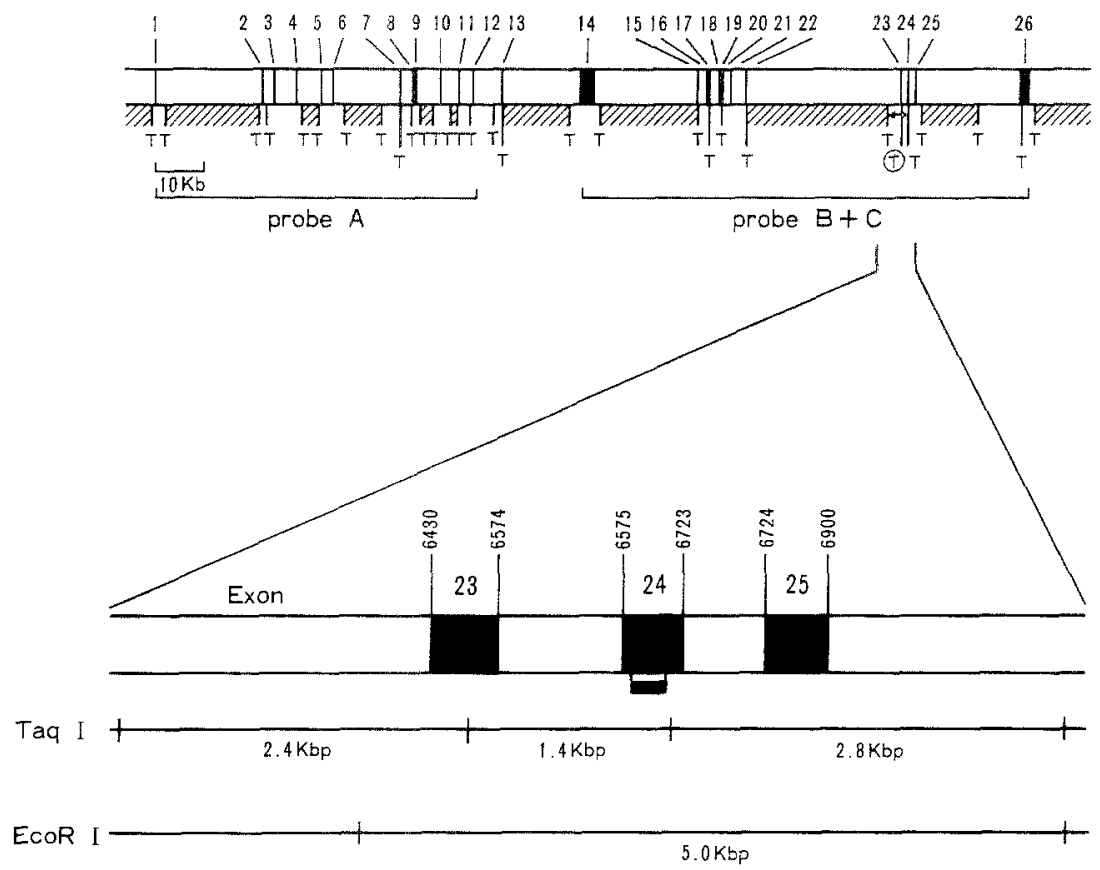

Fig. 1. The restriction map of factor VIII gene using Taq I and the regions detectable with probe $A$ and mixture of probes $B$ and $C$ are shown in the upper part. Restriction map of the surrounding of exons 23 to 25 using TaqI and EcoRI shown below. Black and open boxes represent exons and introns respectively. The restriction fragment lengths are shown on the lower part. The nucleotide positions of cDNA are shown above the exon numbers.

$2.4 \mathrm{kbp}$ fragments when a mixture probe $\mathrm{B}+\mathrm{C}$ was used (Fig. 2, right two columns). These observations strongly suggested that TaqI site in exon 23 had a mutation in the DNA from this patient.

Therefore, the DNA sequence of this TaqI site region was subsequently determined as follows. High molecular weight genomic DNA was prepared by the standard method as described previously (Nishino et al., 1987) from leukocytes of the haemophiliac patient. An EcoRI digest of the DNA was fractionated by gel electrophoresis. A fraction which was 4 to $6 \mathrm{kbp}$ in size was purified and cloned into agt 10 phage vectors. After in vitro packaging, the phage lysate was infected to E. coli host, strain $\mathrm{C} 600$, and screened for the EcoRI fragment, in which the point mutation in the TaqI site was thought to be containing (Fig. 1), using ${ }^{32} \mathrm{P}$-labeled 90 -mer synthetic oligonucleotide corresponding to the cDNA region between nucleotide positions 6591 and 6680 (positions are defined as in Ref.) in exon 24. Eight clones out of $5 \times 10^{5}$ independent clones were positive in plaque hybridization with the probe and four of them were further characterized and shown to have the identical $5.0 \mathrm{kbp} E c o \mathrm{RI}$ fragment. Two ( $2 \mathrm{~F} 8-232$ and $\lambda \mathrm{F} 8-235)$ of these four clones were 

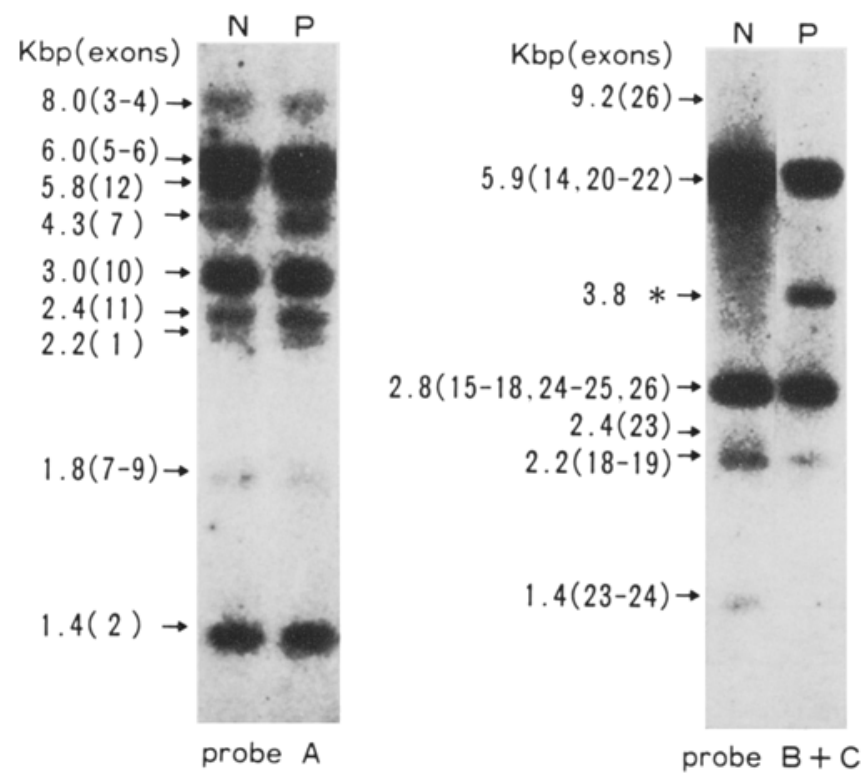

Fig. 2. RFLP analysis of the DNAs leukocytes of patient and normal samples. Autoradiogram of DNAs from normal $(N)$ and patient $(P)$ digested with TaqI and hybridized to probe $\mathrm{A}$ (left panel) or a mixture of probes $\mathrm{B}$ and $\mathrm{C}$ (right panel).

chosen for DNA sequencing. The EcoRI fragments from $\lambda$ F8-232 and $\lambda$ F8-235 were transfered to pHSG399 (Takeshita et al., 1987) at EcoRI site for dideoxy-chain-termination DNA sequencing by using two sequence primers. One primer, TGGCAATGTGGATTCAT (corresponding to the sense sequence between positions 6438 and 6454), was used for the sequencing of the TaqI site region on one sense strand and the other primer, TCACAGCCCATCAACTC between positions 6566 and 6550 on the antisense strand.

Sequence of 300 nucleotides were determined including the TaqI site region (6496 to 6499). Two independent clones showed a completely identical sequence in this region. However, the TaqI site was not found within this region in both two clones. The cytosin residue at nucleotide position 6497 in the normal factor VIII gene was substituted by thymin residue in these clones, resulting in mutation from Arg codon, CGA, to stop codon, TGA (Fig. 3). Therefore, it was concluded that the difference of TaqI RFLP analysis data between normal and the patient and the deficiency of factor VIII activity in this patient was due to the single nucleotide substitution in the TaqI site in exon 23.

\section{DISCUSSION}

In this report, we localized nonsense mutation, from CGA (Arg) to TGA (stop), in exon 23 of factor VIII gene of one haemophiliac patient. 


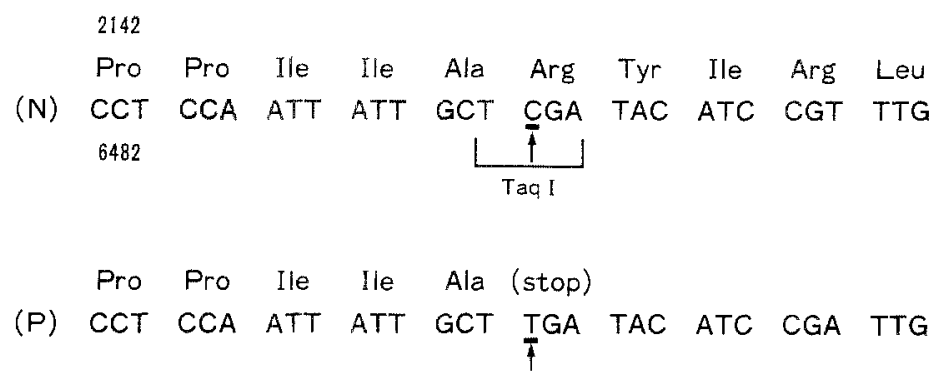

Fig. 3. The normal and mutant partial amino acid and nucleotide sequences in exon 23 . $(\mathrm{N})$ and $(\mathrm{P})$ represent as in Fig. 2. Arrow indicates mutation site.

CpG dinucleotide is a mutation hot-spot (Barker et al., 1984), and 35\% of mutations were found to have occurred within this area in several genetic disorders. According to Cooper and Youssoufian (1988), it has been confirmed that over $90 \%$ of these mutations are $\mathrm{C} \rightarrow \mathrm{T}$ or $\mathrm{C} \rightarrow \mathrm{A}$. Haemophilia $\mathrm{A}$ is one of these disorders. Seven $\operatorname{Taq} \mathrm{I}$ sites are found in exons of factor VIII gene (exons 7, 13, 18, 22, 23, 24, and 26). The TaqI restriction site (TCGA) containing CpG dinucleotide are frequently examined in haemophiliacs by Southern blotting. Thus far, either the $\mathrm{CpG} \rightarrow \mathrm{TpG}$ mutation (Antonarakis et al., 1985; Gitschier et al., 1985; Youssoufian et al., 1986, 1987b; Higuchi et al., 1987; Matthews et al., 1987) or CpG $\rightarrow$ CpA mutation (Gitschier et al., 1986; Bernaldi et al., 1987) has been observed in exons $18,23,24$, and 26 of factor VIII gene. CpG $\rightarrow$ TpG change caused a nonsense mutation from CGA (Arg) to TGA (stop codon), and the CpG $\rightarrow$ CpA change caused a missense mutation from CGA (Arg) to CAA (Gln). Our case had a CpG $\rightarrow$ TpG mutation in exon 23. This mutation is the same as that reported by Matthews et al. (1987). In Southern blot analysis, the abnormality of TaqI RFLP in exon 23 was also found in the mother of the patient. Carrier detection or prenatal diagnosis in this family can be performed by this analysis.

Anti-factor VIII antibodies (inhibitor) have been reported among patients caused by nonsense mutation in exon 18 (Higuchi et al., 1987; Matthews et al., 1987), 23 (Matthews et al., 1987), 24 (Gitschier et al., 1985; Higuchi et al., 1987) and 26 (Higuchi et al., 1987) but not by nonsense mutation in exon 22 (Youssoufian et al., 1986; Higuchi et al., 1987). It has been also reported that missense mutations in exons 24 (Bernardi et al., 1987) and 26 (Gitschier et al., 1986) can cause a formation of anti-factor VIII antibodies (Table 1). It is not easy to explain the relationship between molecular defects and inhibitor development. Several cases with various kinds of gene defects including nonsense, missense and deletion mutations of factor VIII gene were also found to have inhibitor (Antonarakis et al., 1985; Gitschier et al., 1985; Din et al., 1986; Camerino et al., 1986; Higuchi et al., 1987; Mikami et al., 1988). To clarify the relationship, further studies of the defective factor VIII genes and their products should be performed. 
Table 1. Point mutations and inhibitor in patients with haemophilia A. All cases were severe form with nonsense mutation except two missense cases $(*$ and $* *) . \quad(+),( \pm)$ or $(-)$ shows existence of inhibitor.

\begin{tabular}{|c|c|c|c|c|c|}
\hline & \multicolumn{5}{|c|}{ Exon } \\
\hline & 18 & 22 & 23 & 24 & 26 \\
\hline Antonarakis et al. (1985) & $(-)$ & & & & \\
\hline Youssoufian et al. (1986) & $(-)$ & $(-)$ & & & \\
\hline Gitschier et al. (1985) & & & & $(+)$ & $(-)$ \\
\hline Gitschier et al. (1986) & & & & & $(-)^{* *}$ \\
\hline \multirow[t]{2}{*}{ Higuchi et al. (1987) } & $(+)$ & $(-)$ & & $( \pm)$ & $(+)$ \\
\hline & & $(-)$ & & $(+)$ & $(-)$ \\
\hline Matthews et al. (1987) & $(+)$ & & $(+)$ & & $(-)$ \\
\hline Bernardi et al. (1987) & & & & $(-)^{*}$ & \\
\hline
\end{tabular}

* Missense (severe form). ** Missense (mild form).

Acknowledgments We thank Dr. Lewis in Genetics Institute (Massachusetts, USA) for providing factor VIII gene probes, and Drs. Murotsu and Tokino in Institute for Molecular and Cellular Biology, Osaka University for technical help.

\section{REFERENCES}

Antonarakis, S.E., Waber, P.G., Kittur, S.D., Patel, A.S., Kazazian, H.H., Jr., Mellis, M.A., Counts, R.B., Stamatoyannopoulos, G., Bowie, E.J.W., Fass, D.N., Pittman, D.D., Wozney, J.M., and Toole, J.J. 1985. Hemophilia A: Detection of molecular defects and of carriers by DNA analysis. New Engl. J. Med. 313: 842-848.

Barker, D., Schafer, M., and White, R. 1984. Restriction sites containing CpG show a higher frequency of polymorphism in human DNA. Cell 36: 131-138.

Bernardi, F., Bertagnolo, V., Bartolai, S., Rossi, L., Panicucci, F., and Conconi, F. 1987. A point mutation and a gene deletion of factor VIII gene in severe haemophilia A. Thromb. Haemostas. 58: 345 (Abst.).

Camerino, G., Bardoni, B., Sampietro, M., Romano, M., Crapanzano, C., and Mannucci, D.M. 1986. Deletion of part of coagulation factor VIII in a hemophiliac with inhibitor. Ric. Clin. Lab. 16: 227 (Abst.).

Cooper, D.N. and Youssoufian, H. 1988. The CpG dinucleotide and human genetic disease. Hum. Genet. 78: 151-155.

Din, N., Schwartz, M., Kruse, T., Vestergaard, S.R., Ahrens, P., Scheibel, E., Nordfang, O., and Ezban, M. 1986. Factor VIII gene specific probes used to study heritage and molecular defects in hemophilia A. Ric. Clin. Lab. 16: 182 (Abst.).

Gitschier, J., Wood, W.I., Goralka, T.M., Wion, K.L., Chen, E.Y., Eaton, D.H., Vehar, G.A., Capon, D.J., and Lawn, R.M. 1984. Characterization of the human factor VIII gene. Nature 312: $326-330$.

Gitschier, J., Wood, W.I., Tuddenham, E.G.D., Shuman, M.A., Goralka, T.M., Chen, E.Y., and Lawn, R.M. 1985. Detection and sequence of mutations in factor VIII gene of haemophiliacs. Nature 315: 427-430. 
Gitschier, J., Wood, W.I., Shuman, M.A., and Lawn, R.M. 1986. Identification of a missense mutation in the factor VIII gene of a mild hemophiliac. Science 232: 1415-1416.

Hardisty, R.M. and Macpherson, J.C. 1962. A one-stage factor VIII (antihemophilic globulin) assay and its use on venous and capillary plasma. Thromb. Diathes. Haemorrh. 7: 215-229.

Higuchi, M., Kochhan, L., Schwaab, R., Brackmann, H.H., Egli, H., and Olek, K. 1987. Detection. of mutations in hemophilia A. Thromb. Haemostas. 58: 336 (Abst.).

Maniatis, T., Fritsch, E.F., and Sambrook, J. 1982. Molecular Cloning: A Laboratory Manual, Cold Spring Harbor Laboratory, New York.

Matthews, R.J., Peake, I.R., and Bloom, A.L. 1987. Point-mutation of factor VIII coding sequences in haemophilia A. Thromb. Haemostas. 58: 336 (Abst.).

Mikami, S., Nishimura, T., Naka, H., Kuze, K., and Fukui, H. 1988. A deletion involving intron 13 and exon 14 of the factor VIII gene in a haemophiliac patient with anti-factor VIII antibody. Jpn. J. Human Genet. 33: 401-407.

Nishino, M., Nishimura, T., Naka, H., Mikami, S., Tokino, T., and Murotsu, T. 1987. Carrier detection in Japanese haemophilia A families using factor VIII gene probe (F8A) and the genelinked ST14-1 probe. Jpn. J. Human Genet. 32: 237-245.

Peake, I.R., Bloom, A.L., Giddings, J,C., and Ludlam, C.A. 1979. An immunoradiometric assay for procoagulant factor VIII antigen: Results in haemophilia, von Willebrand's disease and fetal plasma and serum. Br. o. Haematol. 42: 269-281.

Sanger, F., Nicklen, S., and Coulson, A.R. 1977. DNA sequencing with chain-terminating inhibitors. Proc. Natl. Acad. Sci. USA 74: 5463-5467.

Takeshita, S., Sata, M., Toba, M., Masahashi, W., and Hashimoto-Gotoh, T. 1987. High-copynumber and low-copy-number plasmid vectors for lacZ $a$-complementation and chloramphenicolor kanamycin-resistance selection. Gene 61: 63-74.

Toole, J.J., Knopf, J.L., Wozney, J.M., Sultzman, L.A., Buecker, J.L., Pittman, D.D., Kaufman, R.J., Brown, E., Shoemaker, C., Orr, E.C., Amphlett, G.W., Foster, W.B., Coe, M.L., Knutson, G.J., Fass, D.N., and Hewick, R.M. 1984. Molecular cloning of a cDNA encoding human antihaemophilic factor. Nature 312: 342-347.

Wood, W.I., Capon, D.J., Simonsen, C.C., Eaton, D.L., Gitschier, J., Keyt, B., Seeburg, P.H., Smith, D.H., Hollingshead, P., Wion, K.L., Delwart, E., Tuddenham, E.G.D., Vehar, G.A., and Lawn, R.M. 1984. Expressions of active human factor VIII from recombinant DNA clones. Nature 312: $330-337$.

Youssoufian, H., Kazazian, H.H., Jr., Phillips, D.G., Aronis, S., Tsiftis, G., Brown, V.A., and Antonarakis, S.E. 1986. Recurrent mutations in haemophilia A give evidence for CpG mutation hot-spots. Nature 324: 380-382.

Youssoufian, H., Antonarakis, S.E., Aronis, S., Tsiftis, G., Phillips, D.G., and Kazazian, H.H., Jr. 1987a. Characterization of five partial deletions of the factor VIII gene. Proc. Natl. Acad. Sci. USA 84: 3772-3776.

Youssoufian, H., Patel, A., Phillips, D., Kazazian, H.H., and Antonarakis, S.E. 1987b. Recurrent mutations and unusual deletion in hemophilia A. Thromb. Haemostas. 58: 336 (Abst.). 